\title{
Rising caesarean section rates: can evolution and ecology explain some of the difficulties of modern childbirth?
}

\author{
W A Liston FRCOG
}

J R Soc Med 2003;96:559-561

There is concern in many countries about rising rates of caesarean section. In England and Wales, for example, the figure is about 22\%, ${ }^{1}$ whereas the World Health Organization favours 10-15\%. Most comments on the rising trend, whether from the medical profession or from the public, express disapproval, an example being the report of a Parliamentary Select Committee. In response, obstetricians in the UK have set up studies such as the National Sentinel Audit (England and Wales) ${ }^{1}$ and the National Audit (Scotland). ${ }^{2}$ In Canada the matter is being addressed by the Ontario Women's Health Project. ${ }^{3}$ These bodies note that in primary emergency caesarean section (i.e. caesarean section in primigravid women in labour) there are two main indications-failure to progress in labour and fetal distress. To counter these they advocate generous use of oxytocin in the failure-to-progress group (a strategy that can precipitate fetal distress) and careful evaluation of the fetus via scalp $\mathrm{pH}$ in the fetal-distress group. But such exhortations have had scant effect on the caesarean section rate. Further, when a caesarean section has been done for the first baby, there is a tendency to deliver subsequent babies in the same way; thus, an increase in the primary caesarean section rate has a multiplier effect on the whole rate. Why is it that modern human childbirth is so frequently associated with difficulty? Only occasionally has anyone attempted to explain this. ${ }^{4}$ While the proximate causes for primary caesarean section are failure to progress and fetal distress, the ultimate causes may lie in changes in human ecology.

\section{EVOLUTION}

Looking around in nature we see that natural selection is a brilliant designer. Richard Dawkins ${ }^{5}$ cites the bat and its echolocation device as an example. Every living organism displays evidence of the complexity and inventiveness of natural selection. Yet, when it comes to 'natural childbirth' modern Homo sapiens performs poorly-despite the mother's investment of huge resources during the nine months of gestation. The explanation is that cultural evolution has outstripped biological evolution.

Department of Obstetrics, Simpson Centre for Reproductive Health, Royal Infirmary of Edinburgh-Little France, 51Little France Crescent,

Edinburgh EH16 4SA, Scotland, UK
The species $H$. sapiens evolved as a large-brained omnivorous primate hunter-gatherer in Africa. Its ancestors were hominid and australopithecans living in Africa who had developed over several million years from earlier primates. Modern H. sapiens emerged in Africa less than 100000 years ago, ${ }^{6}$ and through a combination of cleverness, curiosity and greed spread through all the habitable earth. The large brain contributed to this success but made the process of birth more critical. There is a much tighter fit than in hominid and pongid ancestors between the human infant head and the mother's pelvis.

For most of its history $H$. sapiens lived in its own ecological niche, that of the hunter-gatherer. The total world population was small, possibly 10000000 . The species lived in scattered bands containing 100-150 individuals, nomadic and consuming the edible animals, fruit and vegetables that they encountered. A large amount of exercise was taken to obtain food. A woman's reproductive career began shortly after menarche at the age of $17-18$.

All that changed with the invention of agriculture about 10000 years ago. ${ }^{7}$ With huge increases in population and later industrialization the life of modern woman and man bears little relation to that of the hunter-gatherer. Because biological evolution cannot keep pace, man is a huntergatherer living in a 21 st century world. Admittedly, where selection pressures have been very strong (e.g. malaria and the haemoglobinopathies) there have been genetic changes, but the species retains much of the physiology of preagricultural times. Whereas hunter-gatherers went through tens of thousands of generations there have been only 500 generations of agriculturalists and just a few in the industrial era. Physicians and nutritionists have therefore proposed that certain modern diseases, particularly heart disease and type 2 diabetes, are caused by a maladaption to our current lifestyle. Similar arguments can be applied to reproductive health and obstetric performance.

\section{CHANGES IN HUMAN ECOLOGY}

There are four chief ways in which this misfit between biology and lifestyle could affect childbirth - diet, population density, exercise and reproductive behaviour. The diet in palaeolithic times was by most accounts richer in 
protein and poorer in carbohydrate, with a different pattern of fats. ${ }^{8,9}$ It was also very varied. In particular the carbohydrate component had little refined starch and sugar with much more fibre. The agriculturalists then moved to a diet with less protein and fat, and more complex carbohydrate. The modern western diet contains a superabundance of food, especially sugar and fat with less protein than that of early upper palaeolithic man. In poorer parts of the world where protein is scarce, food consists largely of complex carbohydrate, but western tendencies and fast food are spreading to all parts of the globe. ${ }^{8,9}$

What of population density? The advent of agriculture enabled people to live in villages and cities rather than small settlements, and gave rise to a great increase in population density. In consequence, infectious diseases, especially droplet infection and waterborne disease, became very common particularly in infancy and childhood. Conditions became even worse in the slums of the industrial revolution, where desperate living conditions were compounded by deficiency diseases. ${ }^{10}$ Such conditions are still encountered in mega-cities of the poor world.

What is not widely known is that the invention of agriculture and the development of settled living had pronounced affects on physical stature. Study of skeletons points to adverse changes in the teeth ${ }^{11}$ and a general reduction of height. ${ }^{8,12-14}$ Angel ${ }^{15}$ has charted the patterns over thousands of years. Humans were tall in early upper palaeolithic times and did not become as tall again until the late 20th century in Western Europe and the USA. The rich were always taller than the poor. Better nutrition and living conditions were associated with some increases in stature, but it is only now in prosperous parts of the globe, with adequate children's nutrition and control of infectious diseases by sanitation and vaccination, that humans are again reaching their full potential height. That this process can take several generations is illustrated by data in immigrants to the United States. ${ }^{16}$

With growth in stature goes growth in pelvic size. Short stature has long been known as a risk factor for difficult labour; indeed, the first regular use of caesarean delivery was in short women with contracted pelves. ${ }^{17}$ Baird ${ }^{18}$ emphasized this in Aberdeen in the 1950s, and numerous studies have confirmed it. For example, in Western Australia ${ }^{19}$ primigravid women with height less than $160 \mathrm{~cm}$ had a rate of caesarean section four times that in women over $164 \mathrm{~cm}$. Natural selection designed women to be tall, with good pelvic capacity to allow delivery. Though many women are now tall, large numbers even in prosperous areas, have not grown to their full genetic potential.

Another change noticeable in primiparous women is a rising prevalence of obesity. This reflects a worldwide trend ${ }^{20}$ which results from a combination of lack of exercise and a diet high in refined carbohydrates and fat. Obesity predisposes to difficult labour. A woman with a body mass index $>30$ has nearly three times the risk of caesarean section of a woman with BMI $<20.4,21$ Hunter-gatherers, from such evidence as we have in remnant populations, were largely slim and physically active. ${ }^{22}$

Why obesity has a bad influence on childbirth is not clear. The most plausible explanation is that obese women tend to have large babies: the maternal pre-pregnancy weight is the best marker for fetal weight. ${ }^{23}$ Fat women have bigger babies either because the baby is proportionate to their size or because both birthweight and maternal weight result from maternal diet or components of that diet (e.g. proportions of carbohydrate and protein). ${ }^{24}$ Data from Scotland ${ }^{25,26}$ and China ${ }^{27}$ point to an increase in fetal macrosomia, and it seems that babies are getting bigger as women are getting fatter. Bigger babies undoubtedly have higher caesarean section rates. ${ }^{19,28}$ In communities where the babies are small, the caesarean section rate is low. ${ }^{29}$

The final important change in human ecology is maternal age at first delivery. Hunter-gatherers had their first child when aged 17 or 18 . Culture, education, contraception and abortion have allowed women to delay first childbirth. Wherever we look in the western world, women are putting off having their first baby. ${ }^{30-32}$ This has biological disadvantages, with more infertility, more miscarriages and more caesarean sections. From Baird's ${ }^{18}$ work onwards, many studies point to an increasing incidence of caesarean section with maternal age. Why age has this effect is not obvious. Perhaps labour is made more difficult by changes in the connective tissues and the collagen in the uterus and cervix. $^{33}$ Whereas from a cultural, economic and educational viewpoint there are great advantages in delaying first childbirth, from a biological standpoint increasing maternal age is a disadvantage.

\section{CONCLUSION}

Changes in diet, population density, exercise and reproductive behaviour mean that primigravid women are commonly shorter, older and fatter than is ideal for first childbirth. These adverse factors have been well recorded: a paper by Cnattinguis et al. ${ }^{4}$ was entitled 'Obstacles to reducing cesarean rates in a low cesarean setting: the effect of maternal age, weight, height'; Read et al. showed that primigravidae aged under 20 and over $164 \mathrm{~cm}$ in height had an emergency caesarean rate of $2.0 \%$ while those over 35 and less than $160 \mathrm{~cm}$ had a rate of $30.8 \% .{ }^{19}$ Yet, some audits, including the National Sentinel Audit, have ignored these factors and their importance is not widely appreciated by either the medical professions or the general public. The lowest caesarean rates in the western world are in the 
Nordic countries ${ }^{1}$ and in the Netherlands, where women are tall and there is little disparity between health and nutrition among different sectors of society.

When these anthropomorphic factors are added to influences such as maternal preference we cannot realistically expect rates of caesarean section to decline greatly if at all. But is this such a bad thing? The morbidity from elective caesarean section is extremely low, ${ }^{34}$ though higher than that from straightforward vaginal delivery. There may even be long-term benefits for women's health, such as less pelvic floor damage. The risk to the baby is also less than in primigravid labour. ${ }^{35}$ The main advantage of achieving a vaginal delivery of a first baby is that subsequent vaginal deliveries will be easier for the mother and less risky for the baby. ${ }^{35}$ The financial costs may or may not be greater. ${ }^{34}$ What is clear is that the caesarean sections with the greatest morbidity and mortality for mother and baby are emergency sections after prolonged labour. It is these emergency operations that need to be avoided by better methods of prediction.

There is a widespread perception that the increasing caesarean section rate is driven by obstetricians. This is only partly true, and critics of the profession should acknowledge the strong relevance of age and obesity, and the positive aspects of the operation. For the world in general the best public health policy is to feed and look after children properly, particularly the girls.

\section{REFERENCES}

1 Parajothy S, Thomas J. Royal College of Obstetricians and Gynaecologists Clinical Effectiveness Support Unit. National Sentinel Caesarean Audit Report. London: RCOG Press, 2001

2 Expert Advisory Group on Caesarean section in Scotland. Scottish Programme for Clinical Effectiveness in Reproductive Health. Edinburgh: Clinical Resource and Audit Group, Scottish Executive Health Department, 2001

3 Ontario Women's Health Council. Attaining and Maintaining Best Practices in the Use of Cesarean Sections. Toronto, Ontario: Ontario Women's Health Council, 2000

4 Cnattinguis R, Cnattinguis S, Notzon FC. Obstacles to reducing cesarean rates in a low cesarean setting: the effect of maternal age, height and weight. Obstet Gynecol 1998;92:501-6

5 Dawkins R. The Blind Watchmaker. London: Penguin Books, 1988

6 Cavalli-Sforza LL. Genes, People and Languages (Transl. by M Seilstad). London: Allen Lane Penguin Press, 2000

7 Boyden S. Western Civilisation in Biological Perspective. Oxford: Clarendon Press, 1987

8 Eaton SB, Eaton SB III, Konner MJ. Paleolithic nutrition revisited; a twelve-year retrospective on its nature and implications. Europe J Clin Nutr 1997;51:207-16

9 Bogin B. The evolution of human nutrition. In: Romanucci-Ross L, Moerman DE, Tancredi LR, eds. The Anthropology of Medicine, 3rd edn. Westport: Bergin and Garvey, 1997
10 McMichael AJ. Human Frontiers, Environments and Disease: Past Patterns, Uncertain Futures. Cambridge: Cambridge University Press, 2001

11 Ettinger RL. Epidemiology of dental caries. Dent Clin $N \mathrm{Am}$ 1999;43:679-94

12 Formicola V, Giannecchini M. Evolutionary trends of stature in the upper Paleolithic and Mesolithic Europe. J Hum Evol 1999;36:319-33

13 Nickens J. Stature response as an adaptive response to food production in Mesoamerica. J Archaeol Sci 1976;3:31-41

14 Stini WA. Evolutionary implications of changing nutritional patterns in human populations. Am Anthropol 1971;71:1019-30

15 Angel JL. Paleoecology, paleodemography and health. In: Polgar S, ed. Population Ecology and Social Evolution. The Hague: Mouton, 1975:667-79

16 Bock RD, Sykes RC. Evidence for continuing secular increase in height within families in the United States. Am J Hum Biol 1989;1:143-8

17 Cameron M. The caesarean section: with notes of a successful case. BMJ 1889;i:180-2

18 Baird D. Social factors in obstetrics. Lancet 1949;1:1079-83

19 Read AW, Prendiville WJ, Dawes VP, Stanley FJ. Cesarean section and operative vaginal delivery in low risk primiparous women, Western Australia. Am J Publ Health 1994;84:37-42

20 Kuczmarski RJ, Flegal KM, Campbell SM, Johnson LL. Increasing prevalence of overweight among US adults. JAMA 1994;272:205-15

21 Baeten JM, Bukusi EA, Lambe M. Pregnancy complications among overweight and obese nulliparous women. Am $J$ Pub Health 2001;91:436-40

22 Hiernaux J, Hartono DB. Physical measurements of the adult Hadza of Tanzania. Ann Hum Biol 1980;7:339-46

23 Galtier-Dereure F, Boegner C, Bringer J. Obesity and pregnancy: complications and cost. Am J Clin Nutr 2000;71(suppl):1242S-85S

24 Susser M. Maternal weight gain, infant birth weight, and diet: causal sequences. Am J Clin Nutr 1991;53:1384-96

25 Bonelli SR, Raab GM. Why are babies getting heavier? Comparison of Scottish birth from 1980-1992. BMJ 1997;315:1205

26 Smith GCS. A population study of birth weight and the risk of caesarean section; Scotland 1980-1996. Br J Obstet Gynaecol 2000; $107: 740-4$

27 Liu S, Yao L, Chen Y, Liu Z, Sun M. Study on the trend of changes in fetal macrosomia in Yantai during the past 30 years. Zhonghua Fu Chan Ke Za Zhi 2002;37:469-71

28 Parrish KM, Holt VC, Easterling TR, Connell FA, Logerfo JP. The effect of changes in maternal age parity and birth weight distribution on primary cesarean delivery. JAMA 1994;271:443-7

29 Leeman L, Leeman R. A native American community with a 7\% cesarean delivery rate: does case mix, ethnicity, or labor management explain the low rate? Ann Fam Med 2003;1:36-43

30 Government Statistic Service. NHS Maternity Statistics, England 1998 99 to $2000-01$

31 Dietl J. Trends in birth statistics in Europe. Z Geburtshilfe Neonatol 2002;206:48-50

32 Context data; demography. [www.childpolicyintl.org] Table 2.12 2003

33 Roberts ADG, Cordiner JW, Hart DM, Barlow DH, MacRae D, Leggate I. The variation in cervical hydroxyproline and cervical water with age. BrJ Obstet Gynaecol 1988;95:1159-64

34 Morrison J, Mackenzie IZ. Cesarean section on demand. Semin Perinatol 2003;27:20-33

35 Smith GC, Pell JP, Cameron AD, Dobbie R. Risk of perinatal death associated with labor after previous cesarean delivery in uncomplicated term pregnancies. JAMA 2002;287:2684-90 